Georgia State University

ScholarWorks @ Georgia State University

2013

\title{
On the Size and Determinants of Inter-regional Redistribution in European Countries over the Period 1995-2009
}

\author{
Santiago Lago-Penas \\ University of Vigo, slagop@uvigo.es \\ Albino Prada \\ University of Vigo, aprada@uvigo.es \\ Alberto Vaquero \\ University of Vigo, vaquero@uvigo.es
}

Follow this and additional works at: https://scholarworks.gsu.edu/icepp

Part of the Economics Commons

\section{Recommended Citation}

Lago-Penas, Santiago; Prada, Albino; and Vaquero, Alberto, "On the Size and Determinants of Interregional Redistribution in European Countries over the Period 1995-2009" (2013). ICEPP Working Papers. 35.

https://scholarworks.gsu.edu/icepp/35

This Working Paper is brought to you for free and open access by the International Center for Public Policy at ScholarWorks @ Georgia State University. It has been accepted for inclusion in ICEPP Working Papers by an authorized administrator of ScholarWorks @ Georgia State University. For more information, please contact scholarworks@gsu.edu. 
INTERNATIONAL CENTER FOR PUBLIC POLICY
International Center for Public Policy Working Paper 13-04

March 2013
On the Size and Determinants of Inter-regional Redistribution in European Countries over the Period 1995-2009

Santiago Lago-Peñas

Albino Prada

Alberto Vaquero 
International Center for Public Policy

Working Paper 13-04

\title{
On the Size and Determinants of Inter-regional Redistribution in European Countries over the Period 1995-2009
}

\author{
Santiago Lago-Peñas \\ Albino Prada \\ Alberto Vaquero
}

March 2013

International Center for Public Policy

Andrew Young School of Policy Studies

Georgia State University

Atlanta, Georgia 30303

United States of America

Phone: (404) 651-1144

Fax: (404) 651-4449

Email: hseraphin@gsu.edu

Internet: http://aysps.gsu.edu/isp/index.html

Copyright 2006, the Andrew Young School of Policy Studies, Georgia State University. No part of the material protected by this copyright notice may be reproduced or utilized in any form or by any means without prior written permission from the copyright owner. 


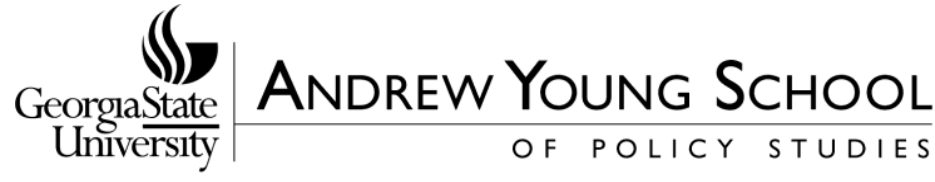

\section{International Center for Public Policy Andrew Young School of Policy Studies}

The Andrew Young School of Policy Studies was established at Georgia State University with the objective of promoting excellence in the design, implementation, and evaluation of public policy. In addition to two academic departments (economics and public administration), the Andrew Young School houses seven leading research centers and policy programs, including the International Center for Public Policy.

The mission of the International Center for Public Policy is to provide academic and professional training, applied research, and technical assistance in support of sound public policy and sustainable economic growth in developing and transitional economies.

The International Center for Public Policy at the Andrew Young School of Policy Studies is recognized worldwide for its efforts in support of economic and public policy reforms through technical assistance and training around the world. This reputation has been built serving a diverse client base, including the World Bank, the U.S. Agency for International Development (USAID), the United Nations Development Programme (UNDP), finance ministries, government organizations, legislative bodies and private sector institutions.

The success of the International Center for Public Policy reflects the breadth and depth of the in-house technical expertise that the International Center for Public Policy can draw upon. The Andrew Young School's faculty are leading experts in economics and public policy and have authored books, published in major academic and technical journals, and have extensive experience in designing and implementing technical assistance and training programs. Andrew Young School faculty have been active in policy reform in over 40 countries around the world. Our technical assistance strategy is not to merely provide technical prescriptions for policy reform, but to engage in a collaborative effort with the host government and donor agency to identify and analyze the issues at hand, arrive at policy solutions and implement reforms.

The International Center for Public Policy specializes in four broad policy areas:

- Fiscal policy, including tax reforms, public expenditure reviews, tax administration reform

- Fiscal decentralization, including fiscal decentralization reforms, design of intergovernmental transfer systems, urban government finance

- Budgeting and fiscal management, including local government budgeting, performancebased budgeting, capital budgeting, multi-year budgeting

- Economic analysis and revenue forecasting, including micro-simulation, time series forecasting,

For more information about our technical assistance activities and training programs, please visit our website at http://aysps.gsu.edu/isp/index.html or contact us by email at hseraphin@gsu.edu. 



\title{
On the Size and Determinants of Inter-regional \\ Redistribution in European Countries over the Period 1995-2009
}

\author{
Santiago Lago-Peñas \\ REDE, University of Vigo and IEB \\ Albino Prada \\ ERENEA and University of Vigo \\ Alberto Vaquero \\ REDE and University of Vigo
}

\begin{abstract}
:
The aim of this paper is to analyse cross-country differences in the degree of interregional redistribution achieved by means of taxes and expenditures in 21 European countries over the period 1995-2009. We rely on a standard approach based on the observation and comparison of both primary and disposable household income at regional scale. Once the redistributive effect in each country is quantified, we try to explain the drivers of cross-country time-series differences. According to our estimates, cross-national standard deviation is significant and much higher than time variation. Secondly, inter-regional redistribution is strongly and positively related to personal redistribution by means of taxes and social benefits in cash; and is negatively related to both the extent of regional disparities in primary income and to the degree of political and fiscal decentralization.
\end{abstract}

Key words: Inter-regional redistribution, regional fiscal imbalance, European Union.

JEL CODES: H11, H23, H77

Acknowledgements: This research project received financial support from the Spanish Ministry of Science and Innovation [Grant code: ECO2010-15553]. 


\section{INTRODUCTION}

Taxes and social benefits in cash change the distribution of income. The analysis of this change can be focused on individuals, giving rise to studies on the incidence of taxes and expenditures. The amount of literature on this is huge, and is tightly connected to the research on income distribution. But the analysis can also focus on spatial incidence. In this case, the focus of interest is usually displayed on inter-regional redistribution and most often pays especial attention to highly decentralized countries with strong regional political arenas (Bosch Espasa, and Solé-Ollé, 2010).

There are a few comparative papers dealing with this spatial incidence, focusing on European countries. Cross-country analysis includes the so-called MacDougall report (MacDougall, 1977). This seminal reference was commissioned by the EU and covered France, United Kingdom, Italy, and Germany. It was then geographically extended by Davezies, Nicot and Prud'homme (1998) to Portugal, Spain and Sweden. Differences in methodology and data sources involve non-coincident results. France and the United Kingdom are again analysed by Melitz and Zumer (2002). The list of papers on single European country analyses is larger. It encompasses works for Spain (LagoPeñas, 2001; Capo and Oliver, 2002; Capó, 2008), Germany (Duboz and Nicot, 1998), and Italy (Obstfeld and Peri, 1988; Decressin, 2002). Disparities in data sources and specifications again make it difficult to compare results. In sum, our knowledge on this issue remains partial and based on heterogeneous empirical evidence.

Hence the aim of this paper is to fill this gap. Our contribution to the literature is threefold.

Firstly, we use a wide and homogeneous database including 21 European countries and 277 regions observed over the period 1995-2009. This new data base for household accounts provided by Eurostat at NUTS2 level provides homogeneous data suitable for cross-country comparisons. Attention is paid to direct taxes and grants on families, meaning that other expenditure and revenue programs are set aside (public health care, business taxes, or European regional policy grants, for instance). The reason for this exclusion is the unavailability of homogeneous and official estimates for 
regional fiscal imbalances ${ }^{1}$. Homogeneity and coverage of our data base is basic to perform cross-country comparisons and establish rankings of countries.

Secondly, we analyse the determinants of cross-country time-series differences on the inter-regional redistribution effect measured in the first step of our analysis. Both economic and institutional drivers are tested. In particular, we take into consideration the extent of welfare states, the diversity in regional per capita primary income to deal with, and the degree of political and financial decentralization. All of them are proven to be relevant. Other factors, such as national per capita GDP, the number of regions, or the European regional policy are not statistically significant.

Finally, the effect of being a rich region in a poor country is analysed. In some countries there are hot political debates on this issue, most often focused on the effects of equalization on regional fiscal menus. This is the case of the province of Ontario in Canada, or of the region of Catalonia in Spain. The most repeated argument is that they are net supporters of inter-regional fiscal flows in their countries, but they have to compete with regions with similar per capita GDP, but which are net receptors of fiscal flows, involving a sort of unfair competition. In the first case, the highly competitive northeast US supports significantly lower levels of equalization than Ontario (Courchene, 1999). In the second one, departments of the South of France with low per capita GDP for French standards are net receptors of fiscal flows while they have similar per capita GDP compared to Catalonia and are direct competitors in some sectors (Prud'homme, 1999). In order to correctly measure the relative efforts made by the different regions, variables are expressed in terms of European averages instead of national averages in this section. Moreover, it gives us the possibility of comparing results for regions with the same per capita primary income in different countries and to identify extreme cases. As before, our attention is focused on household income ${ }^{2}$.

The remainder of this paper is structured as follows. Section 2 is devoted to measuring both cross-national and individual inter-regional redistribution effects.

\footnotetext{
${ }^{1}$ Spain is one of the countries where more efforts have been made on this issue. Official estimates are available. On this issue, see again the collective book edited by Bosch, Espasa and Solé-Ollé (2010). Bosch, Espasa, and Sorribas (2002), Ambrosiano et al (2008), and Hepp and Hagen (2010) perform single-country analyses for Spain, Italy, and Germany, respectively.

2 At the end of the day, arguments on unfair regional fiscal menus and unfair federal redistribution are mixed: if the contribution to federal budget drops, household disposable income increases in richer regions, regional taxes can increase and regional public services improve.
} 
Section 3 analyses the drivers of cross-section time-series variation in the parameter estimates in the previous section. Section 4 is focused on the effect of borders on the relative treatment of regions. Section 5 is the conclusion.

\section{MEASURING THE INTER-REGIONAL REDISTRIBUTION EFFECT}

\subsection{Cross-country analysis}

Following the proposal by Bayoumi and Masson (1995), the point of departure to estimate the inter-regional redistribution effect is the following econometric specification:

$\frac{D I_{i}}{D I_{N}}=\alpha+\beta * \frac{P I_{i}}{P I_{N}}+\varepsilon_{i} \quad[1]$

, where $D I$ is the household disposable income, $P I$ is the household primary income, sub-index $i$ indicates the region, and $N$ the national total $(=100)$. Both variables are expressed in current per capita Euros. Coefficient $\beta$ captures the extent to which differences in primary income are reflected in disposable income. Hence 1- $\beta$ summarizes the average redistribution involved by inter-regional transfers, most of them due to fiscal flows Specification [1] can be extended to capture different inter-regional redistribution parameters for each country, as we do in specification [2]:

$\frac{D I_{i}}{D I_{N}}=\alpha_{i}+\beta_{i} * \frac{P I_{i}}{P I_{N}}+\varepsilon_{i}$

Table 1 reports the list of countries and periods analysed. All data is gathered at NUTS2 level, yielding 277 regions for the 21 countries. For most countries the data is available for all years from 1995 to 2009 . In order to control for potential simultaneity bias (disposable income can affect primary income via short-run demand effects), panel data estimates are discarded, and cross-section datasets built on time-series averages are used $^{3}$. Hence, four estimates were performed: for the whole sample 1995-2009, and for each of the three five-year periods: 1995-1999, 2000-2004, and 2005-2009, in order to analyse the existence of dynamics in the relationship, and to increase the sample size for the estimates in section 4.

\footnotetext{
${ }^{3}$ Moreover, the extremely low within-variation of variables implies that panel data based on annual data was mostly redundant.
} 
Table 1: List of countries and periods analysed

\begin{tabular}{|c|c|c|c|}
\hline Country code & Country name & $\begin{array}{l}\text { Number of regions } \\
\text { (NUTS2) }\end{array}$ & Period \\
\hline 1 & Belgium & 13 & $1995-2009$ \\
\hline 2 & Bulgaria & 8 & $2000-2009$ \\
\hline 3 & Czech Rep. & 8 & $1995-2009$ \\
\hline 4 & Denmark & 5 & $2000-2009$ \\
\hline 5 & Germany & 45 & $1995-2009$ \\
\hline 6 & Ireland & 2 & 1995-2009 \\
\hline 7 & Greece & 16 & 1995-2009 \\
\hline 8 & Spain & 19 & 1995-2009 \\
\hline 9 & France & 24 & $1995-2009$ \\
\hline 10 & Italy & 21 & $1995-2006$ \\
\hline 11 & Hungary & 9 & 2000-2009 \\
\hline 12 & Netherlands & 12 & $1995-2009$ \\
\hline 13 & Austria & 9 & $1995-2009$ \\
\hline 14 & Poland & 16 & 1995-2009 \\
\hline 15 & Portugal & 7 & 1995-2009 \\
\hline 16 & Romania & 8 & $1995-2009$ \\
\hline 17 & Slovenia & 2 & 1999-2009 \\
\hline 18 & Slovakia & 4 & $1995-2009$ \\
\hline 19 & Finland & 5 & $1995-2009$ \\
\hline 20 & Sweden & 8 & 1995-2009 \\
\hline 21 & U. Kingdom & 36 & $1995-2009$ \\
\hline
\end{tabular}

According to the Eurostat methodology ${ }^{4}$, PI shows the income of private households generated directly from market transactions, in particular from the purchase and sale of production factors. This includes the compensation of employees as the main item, i.e. income from the sale of labour as a production factor. Private households can also receive income on assets, particularly interests, dividends and rents. Then there is also income from net operating surplus and self-employment. Interest and rents payable are recorded as negative items for households. The disposable income $(D I)$ of private households is the balance of $P I$ and the redistribution of income in cash. These transactions comprise social contributions paid; cash social benefits received; current taxes on income and wealth paid; as well as other current transfers. Disposable income

\footnotetext{
${ }^{4}$ Available at: http://epp.eurostat.ec.europa.eu/tgm/table.do?tab=table\&init=1\&language $=$ en \&pcode=tgs $00036 \& p l u g i n=$ $\underline{1}$
} 
does not include social transfers in kind coming from public administrations or nonprofit institutions that serve households.

Table 2 reports the main descriptive statistics of variables in specification [1] for the entire period. As expected, while means for both $\frac{D I_{i}}{D I_{N}}$ and $\frac{P I_{i}}{P I_{N}}$ are similar, the standard deviation and variable ranges are significantly lower in the former.

Table 2: Descriptive statistics for cross-country averages (1995-2009)

\begin{tabular}{|c|c|c|c|c|c|c|c|}
\hline Mean & Mean & S.D. & S.D. & Min & Min & Max & Max \\
$\frac{D I_{i}}{D I_{N}}$ & $\frac{P I_{i}}{P I_{N}}$ & $\frac{D I_{i}}{D I_{N}}$ & $\frac{P I_{i}}{P I_{N}}$ & $\frac{D I_{i}}{D I_{N}}$ & $\frac{P I_{i}}{P I_{N}}$ & $\frac{D I_{i}}{D I_{N}}$ & $\frac{P I_{i}}{P I_{N}}$ \\
\hline 97.8 & 96.6 & 12.8 & 17.8 & 60.7 & 56.0 & 148.6 & 183.9 \\
\hline
\end{tabular}

Table 3: The Gini index for $\frac{D I_{i}}{D I_{N}}$ and $\frac{P I_{i}}{P I_{N}}$. Averages for the whole period 1995-2009

\begin{tabular}{|c|c|c|c|}
\hline Country & $\frac{D R_{i}}{D R_{N}}(1)$ & $\frac{P R_{i}}{P R_{N}}(2)$ & $(1)-(2)$ \\
\hline Belgium & 0.054 & 0.079 & -0.025 \\
\hline Bulgaria & 0.070 & 0.100 & -0.030 \\
\hline Czech Rep. & 0.053 & 0.065 & -0.012 \\
\hline Denmark & 0.015 & 0.042 & -0.027 \\
\hline Germany & 0.058 & 0.090 & -0.032 \\
\hline Ireland & 0.038 & 0.058 & -0.020 \\
\hline Greece & 0.057 & 0.067 & -0.010 \\
\hline Spain & 0.085 & 0.105 & -0.020 \\
\hline France & 0.045 & 0.063 & -0.018 \\
\hline Italy & 0.116 & 0.138 & -0.022 \\
\hline Hungary & 0.085 & 0.124 & -0.039 \\
\hline Netherlands & 0.032 & 0.053 & -0.021 \\
\hline Austria & 0.025 & 0.040 & -0.015 \\
\hline Poland & 0.071 & 0.092 & -0.021 \\
\hline Portugal & 0.069 & 0.095 & -0.026 \\
\hline Romania & 0.096 & 0.151 & -0.055 \\
\hline Slovenia & 0.037 & 0.052 & -0.015 \\
\hline Slovakia & 0.106 & 0.162 & -0.056 \\
\hline Finland & 0.062 & 0.091 & -0.029 \\
\hline Sweden & 0.032 & 0.059 & -0.027 \\
\hline U Kingdom & 0.062 & 0.096 & -0.034 \\
\hline Overall & $\mathbf{0 . 0 7 1}$ & $\mathbf{0 . 0 9 9}$ & $\mathbf{- 0 . 0 2 8}$ \\
\hline
\end{tabular}

Table 3 shows the values for the Gini index for $\frac{D I_{i}}{D I_{N}}$ and $\frac{P I_{i}}{P I_{N}}$. This index is calculated on the average values for both ratios over the period 1995-2009. Again, as 
expected, inequality is lower in the former. Bearing in mind that regional revenues are standardized by the corresponding national average and using data for the 277 regions, the Gini index drops from 0.99 for $\frac{D I_{i}}{D I_{N}}$, to 0.71 for $\frac{D I_{i}}{D I_{N}}$. Single-country analyses draw the same picture but also show significant cross-country disparities in primary revenues: Slovakia, Romania and Italy have the highest inequalities in regional revenues (both primary and disposable), whereas Denmark and Austria are the most levelled. Interestingly, regional disparities in Slovakia and Romania is due to the "capital effect". Bratislava and Bucharest concentrate a rising share of GDP and population, with increases in per capita GDP substantially higher than in the rest of the country. On the contrary, inequality in Italy is due to a bimodal distribution without outliers, but with a set of richer regions in the North plus the Mezzogiorno. In figure 1, inserted and explained below, both patterns of inequality are depicted.

The results from econometric estimates of equation [1] are synthesized in Table 4. In order to control for potential cross-country heteroskedasticity, robust errors instead of standard errors are computed. Despite the simplicity of the econometric model, the goodness of fit is very high in all cases, with $\mathrm{R}^{2}$ coefficients ranging between 0.928 and 0.948. The statistical significance of the only regressor is extremely high. While the cross-country average inter-regional redistribution effect $(1-\hat{\beta})$ for the entire period is 0.300 , there is evidence that the intensity of this effect increases slightly over time, from 0.286 for the period 1995-1999, to 0.308 for 2005-2009.

Table 4: Econometric estimates of specification [1]

\begin{tabular}{|c|c|c|c|c|}
\hline Period & $1995-2009$ & $1995-1999$ & $2000-2004$ & $2005-2009$ \\
\hline \multirow{2}{*}{ Intercept } & $30.2^{*}$ & $28.8^{*}$ & $29.8^{*}$ & $31.0^{*}$ \\
& $(29.69)$ & $(16.26)$ & $(21.50)$ & $(20.63)$ \\
\hline$P I_{i}$ & $0.700^{*}$ & $0.714^{*}$ & $0.703^{*}$ & $0.692^{*}$ \\
\hline$I_{N}$ & $(67.59)$ & $(38.43)$ & $(48.65)$ & $(43.95)$ \\
\hline $1-\hat{\beta}$ & 0.300 & 0.286 & 0.297 & 0.308 \\
\hline $\mathrm{R}^{2}$ & 0.943 & 0.928 & 0.942 & 0.948 \\
\hline Observations & 277 & 251 & 277 & 277 \\
\hline
\end{tabular}

Notes: *Indicates statistical significance at $1 \%$. Estimated by OLS, with robust tstatistics in parenthesis. 


\subsection{Individual analysis}

Figure 1 shows the relationship between $\frac{D I_{i}}{D I_{N}}$ and $\frac{P I_{i}}{P I_{N}}$ in all the 21 countries under analysis. The $\frac{D I_{i}}{D I_{N}}$ ratio is represented in the vertical axis, and $\frac{P I_{i}}{P I_{N}}$ in the horizontal axis. While the number of observations (regions) is quite different in each country, the slope of the fit line is positive in all cases and errors remain small. However, the slope of the fit line, and then the extent of inter-regional redistribution, changes. On one end, the fit line for countries like Italy (code 10), Greece (code 7) and Czech Republic (code 3 ) is close to $45^{\circ}$, meaning a proportional relationship between both variables and then no redistribution. However, Denmark is placed in the opposite extreme (code 4).

Specification [2] captures and quantifies this diversity. Its econometric estimation provides the inter-regional redistributive effect reported in the first column of Table $5^{5}$. Countries are ranked by estimated values. As pointed out, Denmark is the country with the strongest inter-regional redistribution effect (0.632), and Italy the weakest $(0.147)$. This exercise is replicated for each of the three five-year periods established above. While rankings do not significantly change, there are however some exceptions and, more interestingly, there is a certain diversity in terms of dynamics. Denmark, Sweden, Austria, United Kingdom, Ireland, Hungary, Slovenia, Poland, Czech Republic, and Italy follow the rising pattern pointed out in Table 3. While on the contrary, redistribution drops in the Netherlands, Romania, Slovakia, Portugal, Belgium, France, Bulgaria, Spain, and Greece. Finally, Germany and Finland follow a quite erratic path. Redistribution increases in Germany during the second period, and then returns to the departure point in the third period; and Finland drops in the second period (ranked $17^{\text {th }}$ ) to sharply rise in the last one (ranked $5^{\text {th }}$ ).

\footnotetext{
5 To avoid inflation of Tables, original estimates are not included in the text. They are available upon request.
} 
Figure 1: Relationship between $\frac{D I_{i}}{D I_{N}}$ and $\frac{P I_{i}}{P I_{N}}$ by countries. Average values for the whole period 1995-2009.

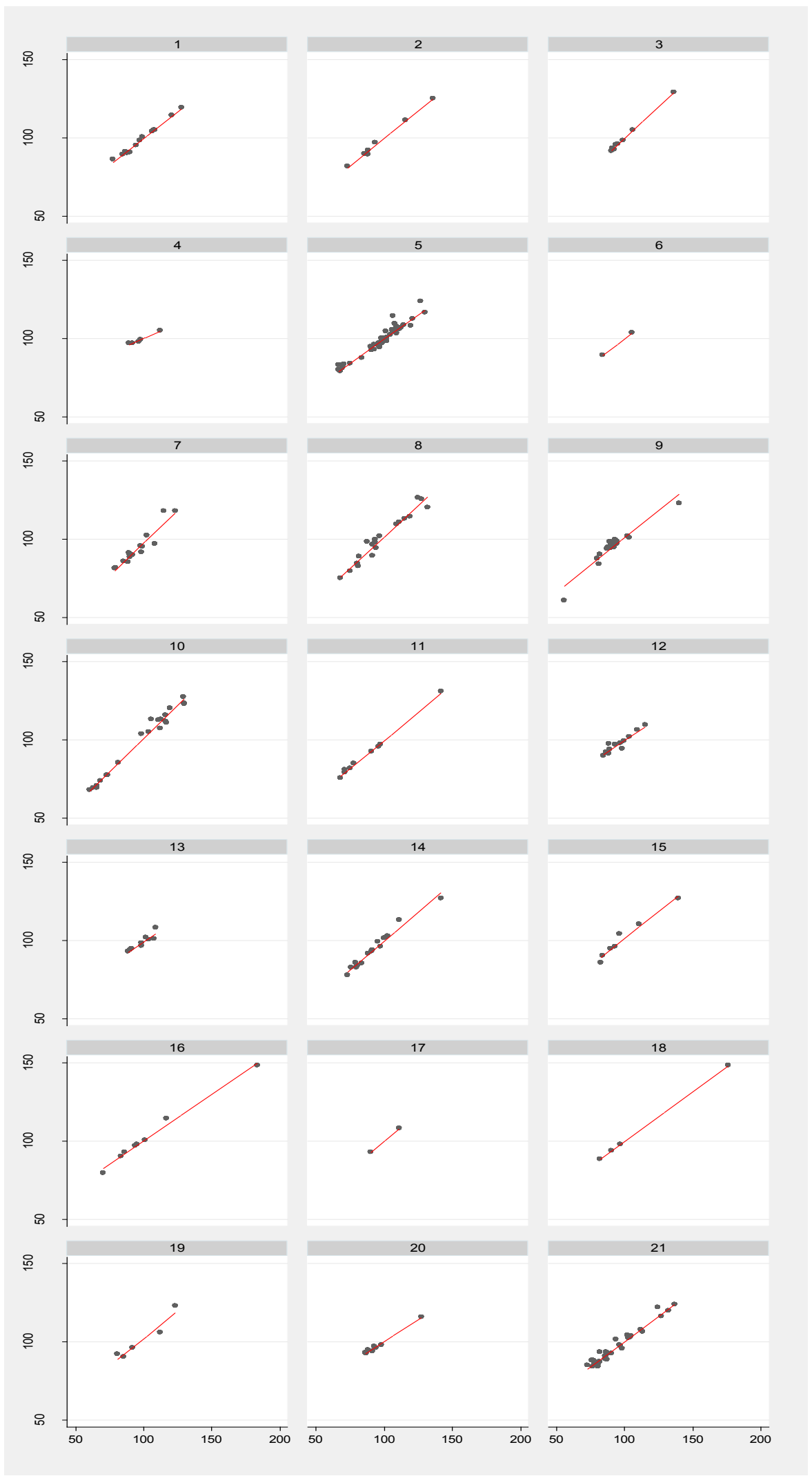

Notes: Country codes in Table $1 . D I$ in the vertical axis, and PI in the horizontal axis 
Table 5: Estimated inter-regional redistribution effects (1- $\beta)$ from Specification [2].

\begin{tabular}{|c|c|c|c|c|}
\hline Country & 1995-2009 & 1995-1999 & $2000-2004$ & $2005-2009$ \\
\hline Denmark & 0.632 & NA & 0.593 & 0.674 \\
\hline Sweden & 0.430 & 0.418 & 0.432 & 0.440 \\
\hline Netherlands & 0.421 & 0.447 & 0.438 & 0.395 \\
\hline Romania & 0.402 & 0.462 & 0.363 & 0.373 \\
\hline Austria & 0.394 & 0.309 & 0.398 & 0.489 \\
\hline Germany & 0.382 & 0.363 & 0.411 & 0.368 \\
\hline Slovakia & 0.367 & 0.425 & 0.355 & 0.331 \\
\hline United Kingdom & 0.353 & 0.331 & 0.348 & 0.372 \\
\hline Ireland & 0.334 & 0.318 & 0.335 & 0.347 \\
\hline Portugal & 0.318 & 0.324 & 0.317 & 0.308 \\
\hline Belgium & 0.309 & 0.324 & 0.297 & 0.307 \\
\hline Cross-country average & 0.300 & 0.286 & 0.297 & 0.308 \\
\hline France & 0.302 & 0.319 & 0.292 & 0.295 \\
\hline Bulgaria & 0.298 & NA & 0.359 & 0.252 \\
\hline Finland & 0.298 & 0.287 & 0.234 & 0.380 \\
\hline Hungary & 0.283 & NA & 0.271 & 0.296 \\
\hline Slovenia & 0.280 & 0.212 & 0.274 & 0.310 \\
\hline Poland & 0.262 & 0.245 & 0.253 & 0.288 \\
\hline Spain & 0.205 & 0.229 & 0.211 & 0.155 \\
\hline Czech republic & 0.190 & 0.126 & 0.203 & 0.222 \\
\hline Greece & 0.155 & 0.187 & 0.160 & 0.154 \\
\hline Italy & 0.147 & 0.134 & 0.153 & 0.170 \\
\hline
\end{tabular}

Notes: Original estimates were computed using OLS with robust errors.

In Table 6, our results are related to those obtained in previous analysis for European countries, as cited above. Starting with France and the UK, Table 5 shows close coefficients for the five-year period 1995-1999, and similar to those reported by Melitz and Zumer (2002). However, trends are different. Redistribution increases over time in the case of the UK, and drops in France. While changes are not dramatic in both cases, the distance between countries increases from 0.051 to 0.077 . All in all, this decline for France was already detected by MacDougall (1977), and by Melitz and Zumer (2002). Moreover, the observed trend for the UK extends the results obtained by MacDougall (1977), and by Davezies, Nicot and Prud'homme (1998) for the period 1997-1993.

In the case of Italy, inter-regional redistribution drops between 1977 (MacDougall, 1977) and 1993 (Davezies, Nicot and Prud'homme, 1998; Decressin, 2002). This trend extends itself to the period 1995-2009, according to our results. For 
Table 6: Studies on inter-regional redistribution. Main results

\begin{tabular}{|c|c|c|c|c|c|}
\hline Author & Period & $\begin{array}{c}\text { Number of } \\
\text { countries/regions }\end{array}$ & Method & Coefficient & Country Ranking \\
\hline MacDougall (1977) & $\begin{array}{c}1969,1970 \\
1973 \\
1964 \\
1970,1973\end{array}$ & $\begin{array}{l}\text { France } \\
\text { Italy } \\
\text { UK } \\
\text { Germany }\end{array}$ & $\begin{array}{c}\text { Primary income/ Disposable } \\
\text { income }\end{array}$ & Gini & $\begin{array}{c}\text { France }(54 \%) \\
\text { Italy }(47 \%) \\
\text { UK }(36 \%) \\
\text { Germany }(29 \%)\end{array}$ \\
\hline Obstfeld and Peri (1998) & $\begin{array}{l}1969-1985 \\
1971-1995 \\
1979-1993\end{array}$ & Italy (10 regions) & $\begin{array}{c}\text { Primary income/ Disposable } \\
\text { income }\end{array}$ & $1-\beta$ & $8 \%$ \\
\hline $\begin{array}{l}\text { Davezies, Nicot and } \\
\text { Prud'homme (1998) }\end{array}$ & 1993 & $\begin{array}{l}7 \text { countries (UK. Spain, } \\
\text { Italy, Sweden, Germany, } \\
\text { Portugal and France) }\end{array}$ & Fiscal Balance & Gini & $\begin{array}{c}\text { UK }(43 \%) \\
\text { Spain }(36 \%) \\
\text { Italy }(23 \%) \\
\text { Sweden }(20 \%) \\
\text { Germany }(20 \%) \\
\text { Portugal }(13 \%) \\
\text { France }(8 \%)\end{array}$ \\
\hline Duboz and Nicot (1998) & 1984-1995 & Germany (11-16 Länder) & $\begin{array}{l}\text { Primary income/ Disposable } \\
\text { income }\end{array}$ & $1-\beta$ & $40 \%$ \\
\hline Lago-Peñas (2001) & $\begin{array}{l}1967-1975 \\
1977-1985 \\
1987-1993\end{array}$ & Spain (17 regions) & $\begin{array}{c}\text { Primary income/ Disposable } \\
\text { income }\end{array}$ & $1-\beta$ & $\begin{array}{l}10 \% \\
22 \% \\
27 \%\end{array}$ \\
\hline Melitz and Zumer (2002) & $1982-1993$ & 2 countries (France, UK) & $\begin{array}{l}\text { Primary income/ Disposable } \\
\text { income }\end{array}$ & $1-\beta$ & $\begin{array}{c}\text { France }(38 \%) \\
\text { UK }(26 \%)\end{array}$ \\
\hline Decressin (2002) & 1983-1992 & Italy (20 regions) & $\begin{array}{l}\text { Primary income/ Disposable } \\
\text { income }\end{array}$ & $1-\beta$ & $21 \%$ \\
\hline Capó and Oliver (2002) & $\begin{array}{r}1967-1997 \\
1967-1977 \\
1979-1997 \\
1967-1997 \\
1967-1977 \\
1979-1997 \\
\end{array}$ & Spain (50 provinces) & $\begin{array}{l}\text { Primary income/ Disposable } \\
\text { income } \\
\text { Primary income/ Disposable } \\
\text { income }\end{array}$ & $1-\beta$ & $\begin{array}{l}25 \% \\
22 \% \\
27 \% \\
27 \% \\
23 \% \\
29 \% \\
\end{array}$ \\
\hline Capó (2008) & $\begin{array}{l}1995-2002 \\
1995-2002\end{array}$ & $\begin{array}{l}\text { Spain (17 regions) } \\
\text { Spain (50 provinces) }\end{array}$ & $\begin{array}{c}\text { Primary income/ Disposable } \\
\text { income }\end{array}$ & $1-\beta$ & $\begin{array}{l}24 \% \\
24 \%\end{array}$ \\
\hline
\end{tabular}




\begin{tabular}{|c|c|c|c|c|c|}
\hline $\begin{array}{l}\text { Lago-Peñas, Prada and } \\
\text { Vaquero (2013) }\end{array}$ & $1995-2009$ & $\begin{array}{l}21 \text { UE countries, } 277 \\
\text { regions }\end{array}$ & $\begin{array}{l}\text { Primary income/ Disposable } \\
\text { income }\end{array}$ & $1-\beta$ & $\begin{array}{c}\text { Sweden }(43 \%) \\
\text { Germany }(38 \%) \\
\text { UK }(35 \%) \\
\text { Portugal }(32 \%) \\
\text { France }(30 \%) \\
\text { Spain }(21 \%) \\
\text { Italy }(15 \%)\end{array}$ \\
\hline $\begin{array}{l}\text { Lago-Peñas, Prada and } \\
\text { Vaquero (2013) }\end{array}$ & $1995-2009$ & $\begin{array}{l}21 \text { UE countries, } 277 \\
\text { regions }\end{array}$ & $\begin{array}{c}\text { Primary income/ Disposable } \\
\text { income }\end{array}$ & Gini (1) & $\begin{array}{c}\text { Sweden }(46 \%) \\
\text { Germany }(36 \%) \\
\text { UK }(35 \%) \\
\text { Portugal }(27 \%) \\
\text { France }(29 \%) \\
\text { Spain }(19 \%) \\
\text { Italy }(16 \%)\end{array}$ \\
\hline
\end{tabular}

Source: Authors own calculation. 
Germany, our estimates show a redistribution effect significantly higher than in both studies. This fact could be explained by the reunification of Germany since 1990, due to the strong inter-regional differences in per capita GDP between western and eastern Länder. For Portugal and Spain, inter-regional redistribution would be much stronger in the latter according to Davezies, Nicot and Prud'homme (1998). On the contrary, econometric estimates reported in Table 5 reveal the opposite. Moreover, our results confirm a sharp decline in the redistribution effect in Spain, in the most recent period (Table 7). Finally, for Sweden we get a rising and stronger effect than in Davezies, Nicot and Prud'homme (1998).

\section{ANALYSIS OF THE DETERMINANTS OF INTER-REGIONAL REDISTRIBUTION}

The aim of this section is to shed light on the determinants of the coefficients reported in columns 2 to 4 of Table 5. As shown in table 7, cross-section differences are significantly higher than within variation. Sluggishness in adjustment implies that econometric specifications have to be dynamic, including lagged values of the endogenous variables as regressors. Hence, the following econometric specification is estimated:

$$
\begin{aligned}
I_{i t} & =\beta_{1}+\beta_{2} \cdot I_{t-1}+\beta_{3} \cdot \operatorname{DISPARITY}_{i t}+ \\
& +\beta_{4} \cdot \operatorname{PERSONAL}_{i t}+\beta_{5} \cdot \operatorname{SOCIAL~}_{i t}+\beta_{6} \cdot \operatorname{SELFRULE}_{i t}+\varepsilon_{i t}
\end{aligned}
$$

Sub-index $i$ indicates country ( $i=1$ to 21 ), and sub-index $t$ indicates the year ( $t=1$ to 3 ). Five exogenous variables are included. Definitions of variables, data sources and expected signs are the following:

- The endogenous variable $I R$ is defined as $1-\beta$. Its values are reported in Table 5.

- DISPARITY is the standard deviation of the ratio $\frac{P R_{i}}{P R_{N}}$. For each five-year period we compute the average of the available data. Our hypothesis is that inter-regional redistribution tends to be more difficult from a political standpoint when inequality is higher. Individuals from richer regions face significant 
incentives to limit the extent of redistribution, and inter-regional redistribution becomes a core issue in public debate, especially but not limited to decentralized countries (Lago-Peñas, 2008; Beramendi, 2012).

- PERSONAL is the sum of direct taxes and grants to households over national GDP. This variable proxies the extent of personal redistribution in each country. In preliminary estimates we include both variables (taxes and grants) separately. However, multi-collinearity was strong. For each five-year period we compute the average of the available data. The expected sign is positive. The dimension of inter-regional flows depends on the national size of both grants and taxes. The data source for this variable is the Eurostat Database-Regional statistics classified by NUTS (http://epp.eurostat.ec.europa.eu/portal/page/portal/statistics/search_database).

- SOCIAL is the collection of social security payments over national GDP. This variable also tries to capture the scope of personal redistribution in each country, but in this case the correlation with PERSONAL (and with both taxes and grants) was not troublesome because of the cross-national diversity in social security arrangements. For each five-year period we compute the average of available data. The expected sign is positive. The data source for this variable is again the Eurostat Database-Regional statistics classified by NUTS.

- SELFRULE is one of the global political, institutional and fiscal decentralization indexes compiled by Hooghe, Marks, and Schakel (2008). For each five-year period we compute the average of the available data. This variable measures the authority exercised by a regional government over those who live in the region, and it is calculated by adding four partial indexes: Fiscal autonomy (the extent to which a regional government can tax its population in an independent way); Policy scope (the range of policies for which a regional government is responsible); the extent to which a regional government is autonomous rather than de-concentrated; and the extent to which a region is endowed with independent legislative and executive powers. In all cases, variables are ordinal and with several categories. Our hypothesis is that inter-regional redistribution is stronger in centralized countries. While in centralized countries individual redistribution by means of taxes and grants are country-wide, in decentralized 
countries fiscal frontiers may be relevant (Beramendi, 2012). Decentralization of tax and grant programs without full fiscal equalization tends to reduce interregional flows. Besides, subnational political actors tend to be stronger in decentralized countries. Regional and nationalist parties in richer regions are prone to limit inter-regional redistribution. As stated by Hicken, Kollman, and Simmons (2010), when political competition at national level occurs between parties that represent specific sub-national constituencies, then the outcomes of policy debates and conflicts can lead to an oversupply of pork-barrel policies and an undersupply of nationally-focused public services.

A few other variables were also included in preliminary estimates, but their statistical significance was very low and hence they were excluded. In particular, we checked national per capita $\mathrm{GDP}^{6}$, the number of regions ${ }^{7}$, and the percentage of objective 1-regions over total regions in each country (Espasa, 2001). Finally, Table 8 reports basic descriptive statistics for all regressors.

Table 7: Main statistics of the redistribution effect reported in columns 2 to 4 of Table 4

\begin{tabular}{|l|c|c|c|c|}
\hline & Mean & Standard deviation & Min & Max \\
\hline Overall & 0.318 & 0.107 & 0.126 & 0.674 \\
\hline Between & & 0.108 & 0.152 & 0.633 \\
\hline Within & & 0.034 & 0.228 & 0.408 \\
\hline
\end{tabular}

Table 8: Main statistics of exogenous variables in specification [4]. Stacked data.

\begin{tabular}{|c|c|c|c|c|}
\hline & Mean & Standard deviation & Min & Max \\
\hline DISPARITY & 18.9 & 10.1 & 5.43 & 55.3 \\
\hline PERSONAL & 25.3 & 7.71 & 12.7 & 45.8 \\
\hline SOCIAL & 15.1 & 4.00 & 7.90 & 25.4 \\
\hline SELFRULE & 3.50 & 3.01 & 0.00 & 9.60 \\
\hline
\end{tabular}

The econometric results are summarised in Table 9. Because lagged values of the endogenous variables are used, we only have two cross-sections for all estimates. Missing values in Table 5 explain the number of observations in columns 1 to 3 (39 instead of $21 * 2=42$ ). In column 1 , a benchmark specification without exogenous

\footnotetext{
${ }^{6}$ So we test the correlation between economic growth and inter-regional redistribution efforts made by governments (Kuznets, 1995)

${ }^{7}$ Disparity in per capita household income can differ depending on the level of aggregation. The number of NUTS2 regions and the average size widely differs between countries.
} 
variables is estimated by Ordinary Least Squares (OLS). The coefficient on the lagged endogenous is very high (0.909), the goodness of fit is high, and the linear correlation between errors, with $\mathrm{t}=3$ and $\mathrm{t}=2$, is quite low. The remaining regressors are included in column 2. The goodness of fit increases up to $\mathrm{R}^{2}=0.86$.

The sign of the coefficients on PERSONAL and SELFRULE are as expected. On the contrary, DISPARITY and SOCIAL are barely significant. In order to control for influential observations (see the boxplot of variable $I R$ in Figure 2), in column 3 the specification is re-estimated performing a robust regression using iteratively reweighted least squares (IRWLS) ${ }^{8}$. The results are basically the same: the statistical significance of SELFRULE increases and the coefficient on the lagged endogenous variable drops.

Table 9: Econometric estimates of specification [3]

\begin{tabular}{|c|c|c|c|c|c|}
\hline & $(1)$ & $(2)$ & $(3)$ & $(4)$ & $(5)$ \\
\hline Intercept & 0.034 & -0.034 & -0.047 & 0.086 & $0.114^{*}$ \\
& $(1.29)$ & $(0.65)$ & $(0.90)$ & $(1.23)$ & $(1.80)$ \\
\hline IR- & $0.909^{* * *}$ & $0.797^{* * *}$ & $0.736^{* * *}$ & $0.725^{* * *}$ & $0.630^{* * *}$ \\
& $(11.13)$ & $(10.40)$ & $(9.74)$ & $(8.30)$ & $(7.94)$ \\
\hline DISPARITY & & -0.0002 & 0.0003 & $-0.0047^{* *}$ & $-0.0053^{* * *}$ \\
& & $(0.21)$ & $(0.38)$ & $(2.42)$ & $(3.01)$ \\
\hline PERSONAL & & $0.0053^{* * *}$ & $0.0069^{* * *}$ & $0.0049^{* * *}$ & $0.0061^{* * *}$ \\
& & $(3.52)$ & $(4.61)$ & $(3.21)$ & $(4.39)$ \\
\hline SOCIAL & & -0.00005 & -0.0004 & -00.14 & -00.19 \\
& & $(0.03)$ & $(0.20)$ & $(0.68)$ & $(1.03)$ \\
\hline SELFRULE & & $-0.0069^{* *}$ & $-0.0097 * * *$ & $-0.0056^{*}$ & $-0.0079^{* * *}$ \\
& & $(2.37)$ & $(3.39)$ & $(2.00)$ & $(3.06)$ \\
\hline R ${ }^{2}$ & 0.770 & 0.858 & & 0.890 & 35 \\
\hline Observations & 39 & 39 & 39 & OLS & IRWLS \\
\hline Method & OLS & OLS & IRWLS & OLS \\
\hline
\end{tabular}

Notes: $* * * . * *, *$ Indicates statistical significance at $1 \%, 5 \%$, and $10 \%$ respectively. $\mathrm{t}-$ statistics are shown in parenthesis.

\footnotetext{
${ }^{8}$ The method begins by fitting the regression, calculating Cook's D and excluding any observation for which $\mathrm{D}>1$. Thereafter the method works iteratively: it performs a regression, calculates case weights from absolute residuals, and regresses again using those weights. Iterations stop when the maximum change in weights drops below tolerance. This method was implemented using the STATA command rreg. The software used was STATA 12.1. See Li (1985).
} 
Figure 2: Boxplot for variable $I R$

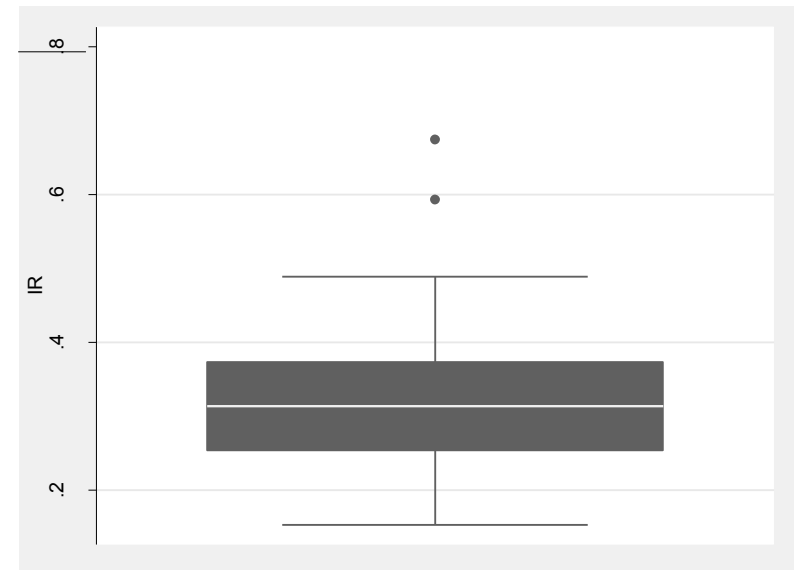

Regarding the variable DISPARITY, we analyse its distribution in-depth. Figure 3 reveals the existence of four outliers (data for Romania and Slovakia), and Figure 4 shows that those observations are very influential on the relationship between $I R$ and DISPARITY. In fact, the linear correlation coefficient increases from -0.19 to -0.62 when the four observations are excluded. Columns 4 and 5 of Table 9, replicate the estimates in columns 2 and 3 excluding those observations. DISPARITY is significant and its coefficient shows the expected sign. Concerning the variable SOCIAL, the results are explained by the fact that the relevance of social contributions in tax systems is very different across countries, without a clear pattern related to inter-regional redistribution. For instance, for the five top countries in terms of inter-regional redistribution in Table 5, the comparative size of SOCIAL is small for Denmark and Romania, big for the Netherlands and Austria, and medium for Sweden.

Figure 3: Boxplot for variable DISPARITY

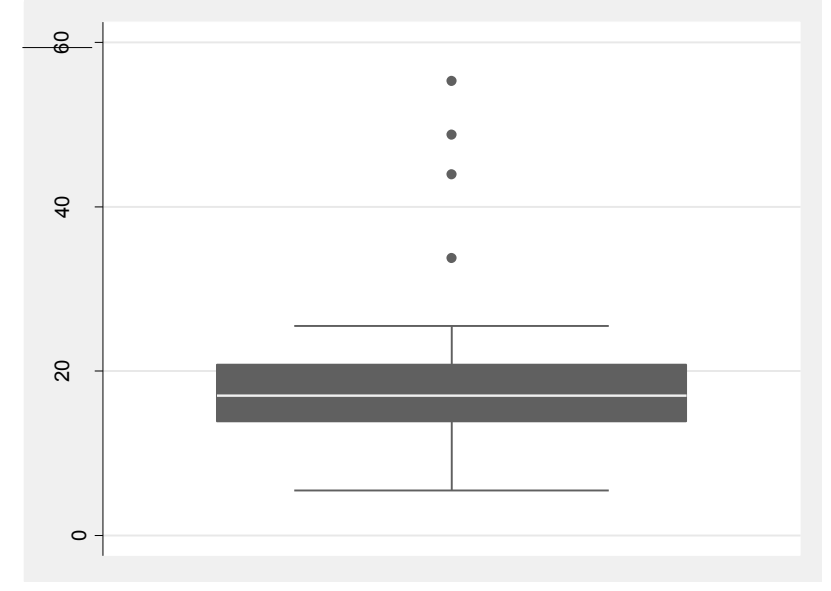


Figure 4: Relationship between IR and DISPARITY

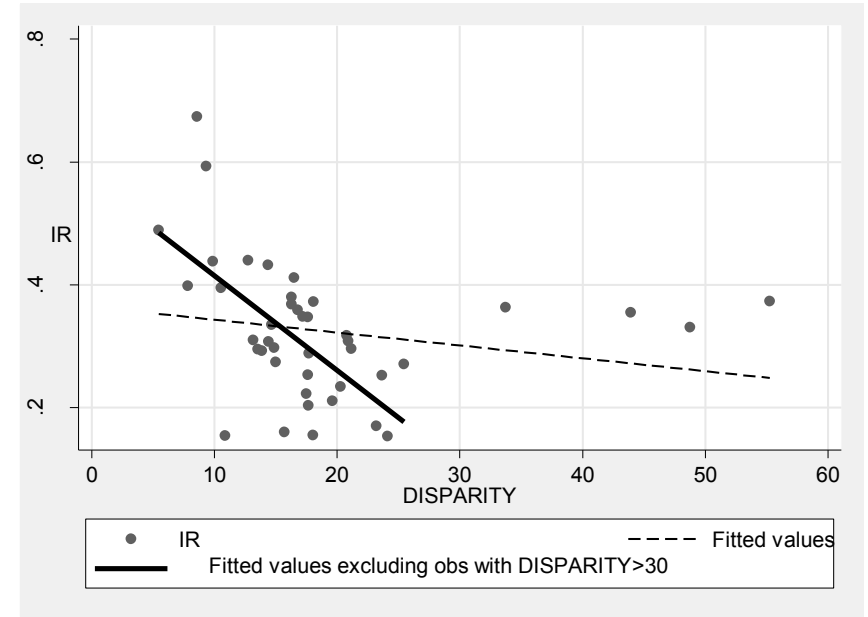

Summarizing, inter-regional redistribution is positively related with the amount of individual direct taxes and government grants, and negatively related with the degree of decentralization and the size of inter-regional divergence in primary income. Interregional fiscal flows tend to be stronger in centralized countries with strong welfare states and moderate regional divergences in economic development.

\section{BEING A RICH REGION IN A POOR COUNTRY: SOME ESTIMATES}

In order to analyse the effect of borders in redistribution, the first step is to standardize variables by the European Union averages instead of using national averages. A second step is to estimate specification [1] using this new statistical definition of variables. Results are shown in Figure 5 and Table 10.

Not surprisingly, the estimated redistributive effect $(1-\hat{b})$ is much lower than in Table 4 (0.300 versus 0.068). Insofar as inter-regional redistribution is basically a national matter, cross-border divergences are not levelled. Regions with the same per capita primary income are subject to significantly different fiscal flows. 
Figure 5: Relationship between DI and PI. Data standardized by the EU average.

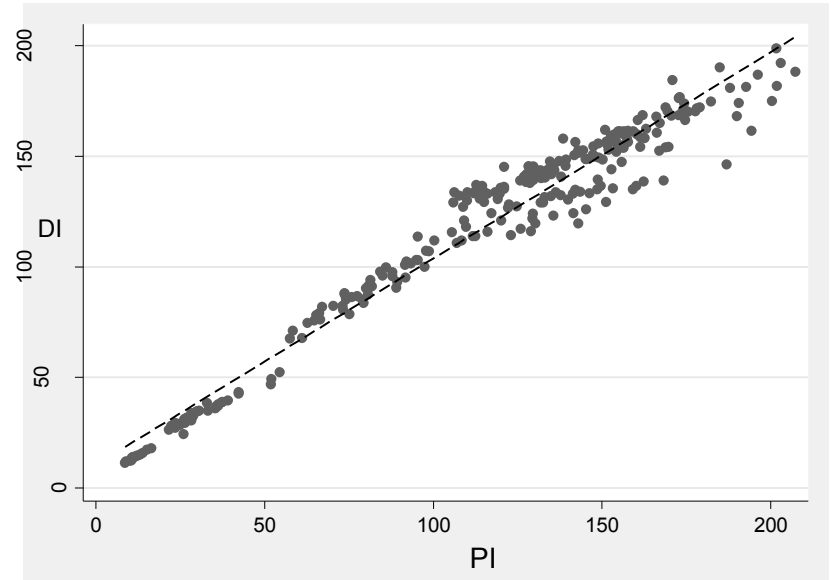

To quantify the redistributive effort or reward (negative effort) of each region, the following index is defined and computed as Effort $t_{i}=\frac{\frac{D I_{i}}{D I_{E U}}-\frac{P I_{i}}{P I_{E U}}}{\frac{P I_{i}}{P I_{E U}}}$. A positive value means that the region benefits from inter-regional redistribution, and the other way around. By construction, the size of the benefit or cost is defined with respect to the level of primary income of each region.

Figure 6 captures the relationship between Effort and the ratio $\frac{P I_{i}}{P I_{E U}}$. As expected, there is a negative and significant relationship $(r=-0.67)$. Negative primes tend to be concentrated in the right part of the figure. However, some regions exhibit negative primes in spite of the relative low level of primary income. The cases of capital cities Bucharest and Bratislava, with primary income 60\% below the EU average, are the most notable. Secondly, there is a wide variation in primes for regions with similar per capita primary income. For each 20-point interval, the extreme cases are reported. Differences in the value for prime exceed 0.3 in some cases and it is around 0.2 in most intervals. Thirdly, regions with very different $I P$ record the same value for Effort. Some striking comparisons are Bremen in Germany $(I P>160)$ with Jugozapaden in Bulgaria 
$(I P<20)$; Lisbon in Portugal with Surrey, East and West Sussex in UK; and Catalonia in Spain with Hamburg in Germany.

Figure 6: Relationship between Effort and PI

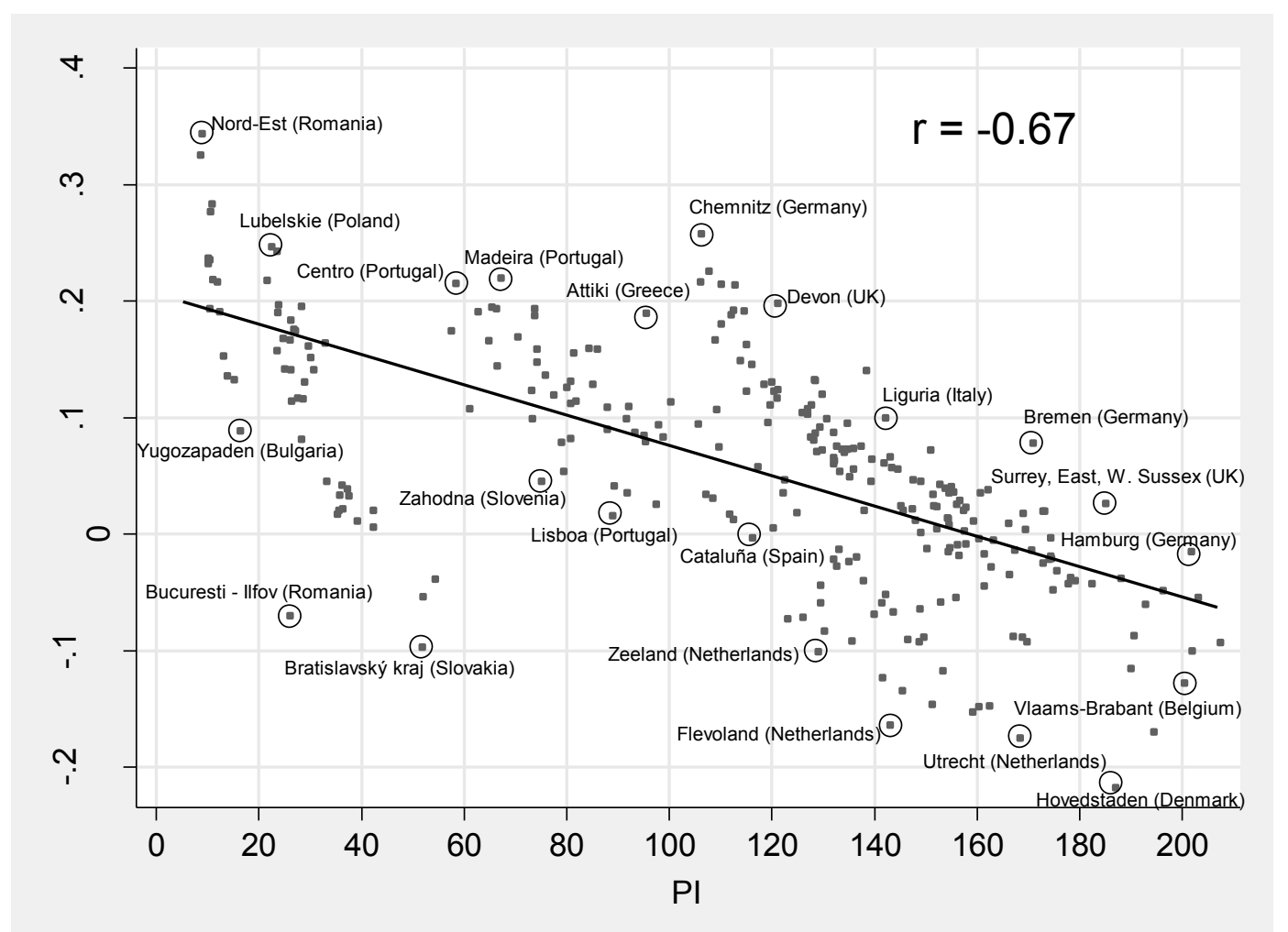

\section{CONCLUSIONS}

According to our results, inter-regional redistribution is significantly different across-countries and it also varies over time. However, between-variation is three times higher than within-variation over the period 1995-2009. For instance, redistribution in Denmark is four times stronger than in Italy or Greece. Definitely there is not something like a "European style" concerning this issue.

Concerning the drivers of differences in redistribution between countries and over time, our estimates show that these effects change slowly. Hence the main driver of the redistribution effect for a given country in period $t$ is the effect in $t-1$. All in all, we show that inter-regional redistribution tends to be lower in countries with wider interregional disparities and with higher levels of both political and fiscal decentralization. 
On the contrary, and as expected, redistribution is positively related to strong personal taxes and personal grants programs, insofar as the main actor implementing those policies is the central government.

We also found that the number of regions, the percentage of objective 1-regions over total regions in each country national per capita GDP, and the weight of social security payments on GDP are not relevant variables. While there is no clear relationship between national per capita GDP and inter-regional redistribution (Table 5), results also reflect that the relevance of social contributions as an instrument to finance Welfare State programs is quite different across-countries, and not as determinant for convergence in disposable income as personal taxes and social benefits in cash. 


\section{REFERENCES}

[1] Ambrosiano, M.F., Bordignon, M. and Cerniglia, F. (2008): "Constitutional reforms, fiscal decentralization and regional fiscal flows in Italy" Quaderni dell'Instituto di Economia e Finanza, 84/2008, Milan.

[2] Bayoumi, T. and Masson, P. R. (1995): "Fiscal flows in the United States and Canada: lessons for monetary union in Europe", European Economic Review, 39: 253274.

[3] Beramendi, P. (2012): The Political Geography of Inequality. Regions and Redistribution, New York, Cambridge University Press.

[4] Bosch, N.; Espasa, M. and Sorribas, P. (2002): "La capacidad redistributiva y estabilizadora del presupuesto del gobierno central español", Hacienda Pública Española/ Public Economics Review, 160: 47-76.

[5] Bosch, N., Espasa, M. and Solé-Ollé, A. (2010): The Political Economy of InterRegional Fiscal Flows: Measurement, Determinants and Effects on Country Stability, Chentelham: Edward Elgar.

[6] Capó, J. and Oliver, X. (2002): "Efecto redistributivo, estabilizador y aseguramiento de la política fiscal", Revista de Economía Aplicada, 29: 59-80.

[7] Capó, J. (2008): "Redistribución y estabilización de la renta a través de la política fiscal”, Hacienda Pública española/Public Economics Review, 184: 9-34.

[8] Courchene, T.J. (1999) "Ontario as a North-America region state", Regional and Federal Studies, 9(3): 3-37.

[9] Davezies, L., Nicot, B.H., and Prud'homme (1998): "Interregional transfers from central government budgets" in Regional Development Studies: Economic and social cohesion in the European Union, European Commission, Luxembourg.

[10] Decressin, J. (2002): "Regional income redistribution and risk sharing: How does Italy compare in Europe?", Journal of Public Economics, 86: 287-306.

[11] Duboz, M.L. and Nicot, B. (1998): "Fédéralisme budgétaire et union monétaire européene: les enseignements de l'expérience allemande", Revue d'économie politique, 108(1): 37-51.

[12] Espasa, M. (2001): "The territorial redistributive power of the EU budget: empirical evidence at national and regional levels", Environment and Planning C: Government and Policy, 19: 771-790.

[13] Hicken, A., Kollman, A. and Simmons, J.W. (2010) "Party System Nationalization and the Provision of Public Health Services", UCLA Comparative Politics Workshop Papers (http://www.sscnet.ucla.edu/polisci/cpworkshop/papers/Hicken.pdf).

[14] Hepp, R. and Von Hagen, J. (2009): "Fiscal federalism in Germany: stabilization and redistribution before and after unification", ZEI working paper B 01-2009, Bonn, (http://faculty.fordham.edu/hepp/vHH_MZ02_Paper_2010_0830_web.pdf). 
[15] Hooghe, Liesbet, Gary Marks, and Arjan H. Schakel. 2008. "Regional Authority in 42 Democracies, 1950-2006: A Measure and Five Hypotheses", Regional and Federal Studies 18(2-3): 111-302.

[16] Kuznets, S. (1955): "Economic growth and income inequality", American Economic Review, 45: 1-28.

[17] Lago-Peñas, S. (2001): "Redistribución y estabilización macroeconómica en las regions españolas: 1967-1993", Hacienda Pública Española/Public Economics Review 158: 53-68.

[18] Lago-Peñas, S. (2008): “Unbalanced Development and Regional Governments: How Much Equalize and How to Equalize?", in Martínez-Vázquez, J. and Vaillancourt, F. (Eds.): Public Policy for Regional Development, Routledge, London, 89-106.

[19] LI, G. (1985): "Robust regression" in D. C. Hoaglin, F. Mosteller, J. W. Tukey (eds.): Exploring Data Tables, Trends, and Shapes, Wiley, New York, 281-340.

[20] MacDougall Report (1977): "Report of the Study Group on the role of public finance in European integration", EC Economic and Financial Series, n. A13 and B13. (http://ec.europa.eu/economy finance/emu history/documentation/chapter8/19770401e n73macdougallrepvol1.pdf).

[21] Mélitz, J. and Zumer, F. (2002): "Regional redistribution and stabilization by the center in Canada, France, the UK and the US: A reassessment and new tests ", Journal of Public Economics, 86: 263-286.

[22] Obstfeld, M. and Peri, G. (1998): "Regional non-adjustment and fiscal policy", Economic Policy, 26: 207-259.

[23] Prud'homme, R. (1993) "The potential role of the EC budget in the reduction of spatial disparities in a European economic and monetary union", in Commission EC, "The Economics of Community Public Finance", European Economy, Reports and Studies, 5. 